University of Nebraska - Lincoln

DigitalCommons@University of Nebraska - Lincoln

U.S. National Park Service Publications and

Papers

National Park Service

$11-23-2019$

\title{
Exposure and potential effects of pesticides and pharmaceuticals in protected streams of the US National park Service southeast region
}

\author{
Paul M. Bradley \\ U.S. Geological Survey, South Atlantic Water Science Center, pbradley@usgs.gov \\ Kristin M. Romanok \\ U.S. Geological Survey, New Jersey Water Science Center \\ Jeffrey R. Duncan \\ National Park Service, Southeast Region, Chattanooga \\ William A. Battaglin \\ U.S. Geological Survey, Colorado Water Science Center \\ Follow this and additional works at: https://digitalcommons.unl.edu/natlpark \\ .limmy M. Clark

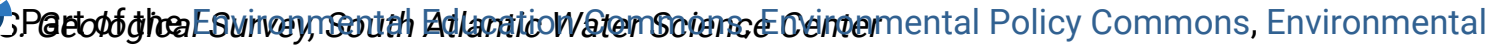 \\ Studies Commons, Fire Science and Firefighting Commons, Leisure Studies Commons, Natural Resource \\ Economics Commons, Natural Resources Management and Policy Commons, Nature and Society \\ See next page for additional authors \\ Relations Commons, Other Environmental Sciences Commons, Physical and Environmental Geography \\ Commons, Public Administration Commons, and the Recreation, Parks and Tourism Administration \\ Commons
}

Bradley, Paul M.; Romanok, Kristin M.; Duncan, Jeffrey R.; Battaglin, William A.; Clark, Jimmy M.; Hladik, Michelle L.; Huffman, Bradley J.; Iwanowicz, Luke R.; Journey, Celeste A.; and Smalling, Kelly L., "Exposure and potential effects of pesticides and pharmaceuticals in protected streams of the US National park Service southeast region" (2019). U.S. National Park Service Publications and Papers. 194.

https://digitalcommons.unl.edu/natlpark/194

This Article is brought to you for free and open access by the National Park Service at DigitalCommons@University of Nebraska - Lincoln. It has been accepted for inclusion in U.S. National Park Service Publications and Papers by an authorized administrator of DigitalCommons@University of Nebraska - Lincoln. 


\section{Authors}

Paul M. Bradley, Kristin M. Romanok, Jeffrey R. Duncan, William A. Battaglin, Jimmy M. Clark, Michelle L. Hladik, Bradley J. Huffman, Luke R. Iwanowicz, Celeste A. Journey, and Kelly L. Smalling 


\title{
Exposure and potential effects of pesticides and pharmaceuticals in protected streams of the US National park Service southeast region
}

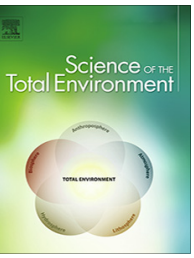

\author{
Paul M. Bradley ${ }^{\mathrm{a}, *}$, Kristin M. Romanok ${ }^{\mathrm{b}}$, Jeffrey R. Duncan ${ }^{\mathrm{c}}$, William A. Battaglin ${ }^{\mathrm{d}}$, Jimmy M. Clark ${ }^{\mathrm{a}}$, \\ Michelle L. Hladik ${ }^{\mathrm{e}}$, Bradley J. Huffman ${ }^{\mathrm{a}}$, Luke R. Iwanowicz ${ }^{\mathrm{f}}$, Celeste A. Journey ${ }^{\mathrm{a}}$, Kelly L. Smalling ${ }^{\mathrm{b}}$ \\ ${ }^{a}$ U.S. Geological Survey, South Atlantic Water Science Center, Columbia, SC USA \\ ${ }^{\mathrm{b}}$ U.S. Geological Survey, New Jersey Water Science Center, Lawrenceville, NJ USA \\ ' National Park Service, Southeast Region, Chattanooga, TN USA \\ ${ }^{\mathrm{d}}$ U.S. Geological Survey, Colorado Water Science Center, Denver, CO USA \\ e U.S. Geological Survey, California Water Science Center, Sacramento, CA USA \\ ${ }^{\mathrm{f}}$ U.S. Geological Survey, Leetown Science Center, Kearneysville, WV USA
}

\section{H I G H L I G H T S}

- Designed-bioactive contaminants assessed in 5 southeast US NPSprotected streams.

- 334 unique pesticides and pharmaceuticals were assessed in water; $24 \%$ were detected.

- 119 sediment pesticides assessed; 5 detected consistently but only in one stream.

- Common exceedances of effectsscreening threshold raise sub-lethal effects concerns.

- Importance of up-gradient external sources suggest increased community engagement.

\section{A R T I C L E I N F O}

\section{Article history:}

Received 12 September 2019

Received in revised form 6 November 2019

Accepted 6 November 2019

Available online 23 November 2019

\section{Keywords:}

Designed bioactive contaminants

pesticides

pharmaceuticals

water quality

sediment quality
G R A P H I C A L A B S T R A C T

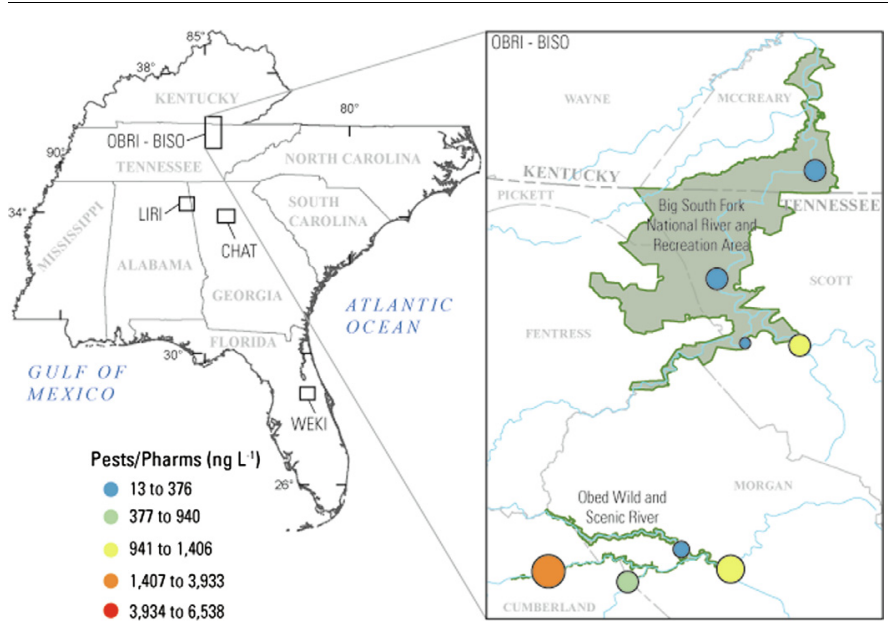

\begin{abstract}
A B S T R A C T
Globally, protected areas offer refugia for a broad range of taxa including threatened and endangered species. In the United States (US), the National Park Service (NPS) manages public lands to preserve biodiversity, but increasing park visitation and development of surrounding landscapes increase exposure to and effects from bioactive contaminants. The risk (exposure and hazard) to NPS protected-stream ecosystems within the highly urbanized southeast region (SER) from bioactive contaminants was assessed in five systems based on 334 pesticide and pharmaceutical analytes in water and 119 pesticides in sediment. Contaminant mixtures were common across all sampled systems, with approximately $24 \%$ of the unique analytes (80/334) detected at least once and 15\% (49/334) detected in half of the surface-water samples. Pharmaceuticals were observed more frequently than pesticides, consistent with riparian buffers and concomitant spatial separation from non-point pesticide sources in four of the systems. To extrapolate exposure data to biological effects space, site-specific cumulative exposure-activity ratios $\left(\Sigma_{\text {EAR }}\right)$ were calculated for detected surface-water contaminants with available ToxCast data; common exceedances
\end{abstract}

\footnotetext{
* Corresponding author at: aU.S. Geological Survey, South Atlantic Water Science Center, Columbia, SC USA.

E-mail address: pbradley@usgs.gov (P.M. Bradley).
} 
of a $0.001 \Sigma_{\mathrm{EAR}}$ effects-screening threshold raise concerns for molecular toxicity and possible, sub-lethal effects to non-target, aquatic vertebrates. The results illustrate the need for continued management of protected resources to reduce contaminant exposure and preserve habitat quality, including prioritization of conservation practices (riparian buffers) near stream corridors and increased engagement with upstream/up-gradient property owners and municipal wastewater facilities.

Published by Elsevier B.V.

\section{Introduction}

In the United States (US) and globally, protected areas are essential biodiversity preserves and environmental-change reference ecosystems (Foresta, 2013; Gaston et al., 2008; Stein et al., 2008), but these services are undermined by the impacts (e.g., water and sediment contamination, disconnection from external wildland corridors, invasive species) of increasing visitation and surrounding-land development (Gaston et al., 2008; Jenkins et al., 2015; Joppa et al., 2008; Palomo et al., 2013; Radeloff et al., 2010). In the US, the National Park Service (NPS) has identified the occurrence and potential adverse effects of anthropogenic bioactive contaminants on park ecosystems as resource management concerns (Landewe 2008) and several recent US Geological Survey (USGS)-NPS studies have demonstrated that intra-park human-waste management as well as fluvial and visitationmediated contaminant transport into parks from external sources are challenges for NPS surface-water ecosystems (Battaglin et al., 2018; Bradley et al., 2017c; Egler et al., 2013; Elliott and VanderMeulen, 2017; Landers et al., 2008; Landewe 2008; Mast et al., 2006; Usenko et al., 2007; Weissinger et al., 2018). Notably, the frequent detection and diversity of bioactive-contaminant mixtures in water and sediment at the floodplain-dominated Congaree National Park near Columbia, SC (Bradley et al., 2017a; Bradley et al., 2017c) highlighted growing concerns for adverse aquaticecosystem effects from surrounding development (Radeloff et al., 2005; Radeloff et al., 2010) within the rapidly urbanizing southeastern US (Terando et al., 2014; Van Metre et al., 2019).

Pesticides and pharmaceuticals originate on the landscape from numerous human and agricultural sources, are ubiquitous in surface water, and are engineered to affect biological systems (Dong et al., 2015; Focazio et al., 2008; Kidd et al., 2014; Kolpin et al., 2002; Rosi-Marshall et al., 2013). Pesticides (biocides designed for direct environmental application) are common in aquatic habitats, accumulate in surface-water sediment, and directly threaten non-target species including, notably, aquatic invertebrates, but also amphibians (Battaglin et al., 2016; Mann et al., 2009; Smalling et al., 2015) and fish (Ackerman et al., 2008; Mast et al., 2006; Mast et al., 2007; Nowell et al., 2009; Nowell et al., 2014; Ryberg and Gilliom, 2015; Ryberg et al., 2014; Stone et al., 2014; Usenko et al., 2007). Pharmaceuticals target molecular endpoints (often endpoints evolutionarily conserved in multiple non-target species) (Brown et al., 2014; Carter et al., 2015; Gunnarsson et al., 2008; Gunnarsson et al., 2012; McRobb et al., 2014), have high aqueous mobility (Daughton and Brooks, 2011; Daughton and Ternes, 1999) and pH-variable toxicity (Boström and Berglund, 2015), and typically occur as complex cocktails (Bradley et al., 2016; Vasquez et al., 2014) with a corresponding broad range of potential adverse outcomes in aquatic foodwebs (Brodin et al., 2013; Brönmark and Hansson, 2012; Corcoran et al., 2010; Giacomini et al., 2016; Hughes et al., 2012; Kidd et al., 2014; Li, 2014; Monteiro and Boxall, 2010; Painter et al., 2009; Rosi-Marshall and Royer, 2012; Schultz et al., 2011; Van Donk et al., 2015). The potential risk (exposure, hazard) (Bradley et al., 2019; Moretto et al., 2017; Norton et al., 1992; Rodier and
Norton, 1992) from designed-bioactive contaminants in surfacewater dominated NPS units within the heavily populated southeastern US is unknown and a critical management data gap, in light of the well-documented potential for adverse impacts of pesticides and pharmaceuticals in aquatic ecosystems (Dong et al., 2015; Focazio et al., 2008; Kidd et al., 2014; Kolpin et al., 2002; RosiMarshall et al., 2013), the extensive and variable contaminant mixtures reported in southeastern US streams (Bradley et al., 2019; Bradley et al., 2016), and the growing evidence for pesticide and pharmaceutical contaminants in diverse NPS parks and stream settings, including remote backcountry locations (Battaglin et al., 2018; Bradley et al., 2017c; Elliott and VanderMeulen, 2017; Landers et al., 2008; Landewe 2008; Mast et al., 2006; Smalling et al., 2013; Usenko et al., 2007; Weissinger et al., 2018).

Many park units within the NPS are dominated by streams and riparian ecosystems and are administered by the NPS under multiple (e.g., National Preserve, National Recreation Area, National River, Wild and Scenic River) management categories. The risk of pesticide and pharmaceutical contaminant impacts in these systems is magnified by their unique ecological characteristics and management mandates (e.g., "to preserve natural resources unimpaired for future generations"), proximity to existing urban areas, and susceptibility to disconnection from external wildland corridors due to their tendency to attract surrounding development (Radeloff et al., 2005; Radeloff et al., 2010). Herein, we assess the potential aquatic-ecosystem risk (exposure and hazard) (Moretto et al., 2017; Norton et al., 1992; Rodier and Norton, 1992) of mixed pesticide and pharmaceutical contamination in five NPS-managed stream systems in the southeastern US. Results for stream-water samples collected during 2015-2017 were aggregated, as described (Bradley et al., 2019), to estimate maximum and median surface-water exposure conditions within a contaminant space of 334 unique analytes. Sediment pesticide (119 unique analytes) concentrations were also assessed once (2017) in select locations. Two lines of evidence were employed to assess the potential for cumulative contaminant effects (hazard) to in-stream biota: 1) occurrence and cumulative concentrations of designed-bioactives, and 2) cumulative Exposure Activity Ratios ( $\sum_{\mathrm{EAR}}$ ) (Blackwell et al., 2017; Bradley et al., 2019; Bradley et al., 2018b) based on high-throughput screening data in Toxicity Forecaster (ToxCast ${ }^{\mathrm{TM}}$, U.S. Environmental Protection Agency, 2019).Table 1

\section{Material and methods}

\subsection{Sample locations and chemical analyses}

Water samples were collected during 2015-17 from 3 to 4 sites, including eponymous streams and primary tributaries, in five southeast region NPS-managed stream systems (Figures 1 and S1; Tables 1 and S1) selected to provide broad geographic cover within the southeast region and a range of management categories (Recreation Area, Wild and Scenic River, Preserve). Sites are identified, herein, by system abbreviations (OBRI, Obed Wild and Scenic River; BISO, Big South Fork National River and Recreation Area; LIRI, Little River Canyon National Preserve; CHAT, Chattahoochee 
Table 1

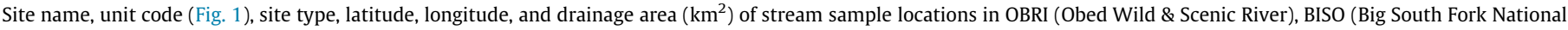

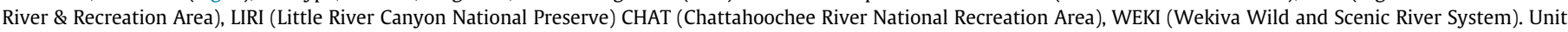
code numbers increase in downstream order.

\begin{tabular}{|c|c|c|c|c|c|}
\hline Site & Code & Type & Latitude & Longitude & Drainage \\
\hline Obed River (Potter's Ford) & OBRI-1 & Main & 36.07285 & -84.90273 & 278.2 \\
\hline Daddys Creek & OBRI-2 & Trib & 36.05841 & -84.79300 & 450.1 \\
\hline Clear Creek & OBRI-3 & Trib & 36.10313 & -84.71828 & 440.3 \\
\hline Obed River (above Emery R) & OBRI-4 & Main & 36.07591 & -84.64994 & 1346.8 \\
\hline New River & BISO-1 & Main & 36.38552 & -84.55472 & 989.4 \\
\hline Clear Fork & BISO-2 & Trib & 36.38829 & -84.63019 & 704.5 \\
\hline South Fork Cumberland River (Leatherwood) & BISO-3 & Main & 36.47738 & -84.66937 & 2087.5 \\
\hline South Fork Cumberland River (Stearns) & BISO-4 & Main & 36.62702 & -84.53327 & 2470.9 \\
\hline Little River (Martha's Falls) & LIRI-1 & Main & 34.38873 & -85.62033 & 365.7 \\
\hline Little River (Eberhart) & LIRI-2 & Main & 34.35052 & -85.67233 & 431.8 \\
\hline Little River (Blue Pond) & LIRI-3 & Main & 34.28898 & -85.68052 & 515.4 \\
\hline Chattahoochee River (Buford) & CHAT-1 & Main & 34.15694 & -84.07889 & 2693.6 \\
\hline Chattahoochee River (Norcross) & CHAT-2 & Main & 33.99722 & -84.20194 & 3030.3 \\
\hline Chattahoochee River (Roswell) & CHAT-3 & Main & 33.98593 & -84.31604 & 3159.8 \\
\hline Chattahoochee River (US 41) & CHAT-4 & Main & 33.86816 & -84.45382 & 3729.6 \\
\hline Wekiwa Springs & WEKI-1 & Main & 28.71222 & -81.45979 & 0.1 \\
\hline Wekiva River (Sanford) & WEKI-2 & Main & 28.81527 & -81.41924 & 489.5 \\
\hline Blackwater Creek & WEKI-3 & Trib & 28.87444 & -81.48972 & 326.3 \\
\hline
\end{tabular}

River National Recreation Area; WEKI, Wekiva Wild and Scenic River System) and a sequential number indicating the relative downstream order of the main-stem sample locations and of the confluence with sampled tributaries. At each site, surface water was collected in a new sterile polypropylene syringe (triple rinsed with site water) and $10-\mathrm{mL}$ samples were syringe filtered $(25 \mathrm{~mm}$ diameter, $0.7 \mu \mathrm{m}$ pore size glass-fiber; pre-rinsed with $10 \mathrm{~mL}$ site water) into separate $20-\mathrm{mL}$ baked $\left(500{ }^{\circ} \mathrm{C}\right)$ amber glass vials and capped. All samples were shipped on ice overnight to the USGS National Water Quality Laboratory (NWQL) in Denver, Colorado for analysis of 113 human-use pharmaceuticals, pharmaceutical metabolites, and polar organic compounds (Furlong et al., 2014) and 224 pesticides and pesticide metabolites (Sandstrom et al., 2016) by direct aqueous injection (DAI) liquid chromatography tandem mass spectrometry (LC-MS/MS). Surface-water extracts (solid phase extraction [SPE] into methanol) were screened for estrogenic, androgenic and glucogenic activity (Bradley et al., 2018b; Conley et al., 2017). Sediment grab samples were collected from select water sample locations in $125-\mathrm{mL}$ combusted $\left(500^{\circ} \mathrm{C}\right)$, amber glass jars, as described previously (Weissinger et al., 2018), extracted using an accelerated solvent extraction (ASE) system followed by SPE to reduce matrix interferences, and analyzed for 119 pesticides by gas chromatography mass spectrometry (GC-MS), as described in detail (Hladik and McWayne, 2012). Site, sample collection, analytical method, quality assurance, and sample data are provided in Supplemental Data Tables S1- S5 and available for download from the USGS National Water Information System (U.S. Geological Survey, 2019) and from (Romanok and Bradley, 2019).

\subsection{Quality assurance quality control (QAQC)}

Four water blanks for pesticides and pharmaceuticals were prepared in the field (BISO4, CHAT1, CHAT2, LIRI3), as described above for samples, with Pesticide/Volatile Organic Chemical grade water; no analytes were detected in water field blanks (Table S3a). Two sediment blanks (coarse sand combusted at $500{ }^{\circ} \mathrm{C}$ for $24 \mathrm{~h}$ and transferred to sample bottles under field conditions) were prepared in 2015 for application to this and the Congaree National Park study (Bradley et al., 2017a; Bradley et al., 2017c); no pesticide analytes were detected in sediment field blanks (Bradley et al., 2017a; Bradley et al., 2017c). LC-MS/MS pharmaceutical and pesticide water analyses included addition of 20 and 21 stable-isotope surrogate standards, respectively, to field-filtered samples to evaluate whole-method recovery (pharmaceuticals median: $102 \%$, interquartile range [IQR]: $96-110 \%$, range: $2-$ 270\%; pesticides median: 101\%, IQR: $95-105 \%$, range: $34-135 \%$ ) (Table S4).

\subsection{Data handling, statistics, and $\sum_{E A R}$ analysis}

The reporting limits for water and sediment analytes were determined using DQCALC software (RLDQC)(ASTM International, 2018) or based on the long-term method-detection level (MDL) (Childress et al., 1999; U.S. Environmental Protection Agency, 2005), respectively (Table S2). Laboratory-estimated water concentrations below the RLDQC (positive detections with reduced quantitative certainty) were used as is (Tables S3a-S3c). Results for all analytes detected in water were aggregated into summary data matrices to estimate maximum (maximum concentration) and central-tendency (median concentration) exposure scenarios within this study's 334-compound contaminant space. Table S3b includes the maximum detected concentrations of all analytes detected at least once in this study by compound and site. Table S3c contains median concentrations (all samples) by compound and site and only includes target analytes that were detected in at least half of the samples at one or more sites. Integrated effects of detected pesticide and pharmaceutical contaminants in water were estimated using the toxEval R-program (De Cicco et al., 2018) to sum (concentration addition (CA) model (Altenburger et al., 2013; Altenburger et al., 2012; Cedergreen et al., 2008; Ermler et al., 2011; Kortenkamp et al., 2009; Thrupp et al., 2018)) individual EAR (ratio of detected maximum or median concentration to activity concentration at cutoff (ACC) from Toxicity ForeCaster (ToxCast ${ }^{\mathrm{TM}}$; U.S. Environmental Protection Agency, 2019) high-throughput screening data (U.S. Environmental Protection Agency, 2018a, 2018b) to provide site-specific cumulative EAR ( $\sum_{\text {EAR }}$ (Becker et al., 2015; Blackwell et al., 2017; Li et al., 2017; Schroeder et al., 2016). EAR $\geq 1$ indicate exposures demonstrated to modulate molecular targets in vitro, whereas EAR $\leq 1$ suggest proportionately lower probability of biological activity. A recent cross-examination of surface-water contaminants, for which both ToxCast and aquatic-toxicity benchmark data were available, indicated correspondence between the commonly employed 0.1 benchmark-based Toxicity Quotient threshold of concern and EAR $=0.001$ (Corsi et al., 2019). Non-specificendpoint, baseline, and unreliable response-curve assays were excluded (as described in Becker et al., 2015; Blackwell et al., 
2017; Li et al., 2017; Schroeder et al., 2016)(Table S6). EEAR results are summarized in Tables S7 and S8 for maximum and median water exposure conditions, respectively.

\section{Results and discussion}

\subsection{Protected-stream pesticide and pharmaceutical surface-water exposures}

Pesticide and pharmaceutical mixtures of varying composition were common in water samples across all five protected-stream systems in this study (Figs. 1-3 and S1-S2; Tables S3a-S3c). All detections were attributed to environmental contaminants, as no analytes were detected in any of the four water blanks (Table S3a) or the two sediment blanks (Bradley et al., 2017a; Bradley et al., 2017c) prepared for this study. Approximately $24 \%$ (80) of the 334 unique (accounting for method overlap) analytes assessed in water in this study were detected at least once (maximum exposure dataset) across all sites (Figs. 1-3, Table S3b). Approximately 15\% (49/334) were detected in at least half of the samples from one or more sites in this study (median exposure dataset; Fig. 3, S1-S2, Table S3c). For comparison, approximately 55\% (1 84 4) and 30\% (99) of the same analytical space (pesticide and pharmaceutical) were detected under the estimated maximum
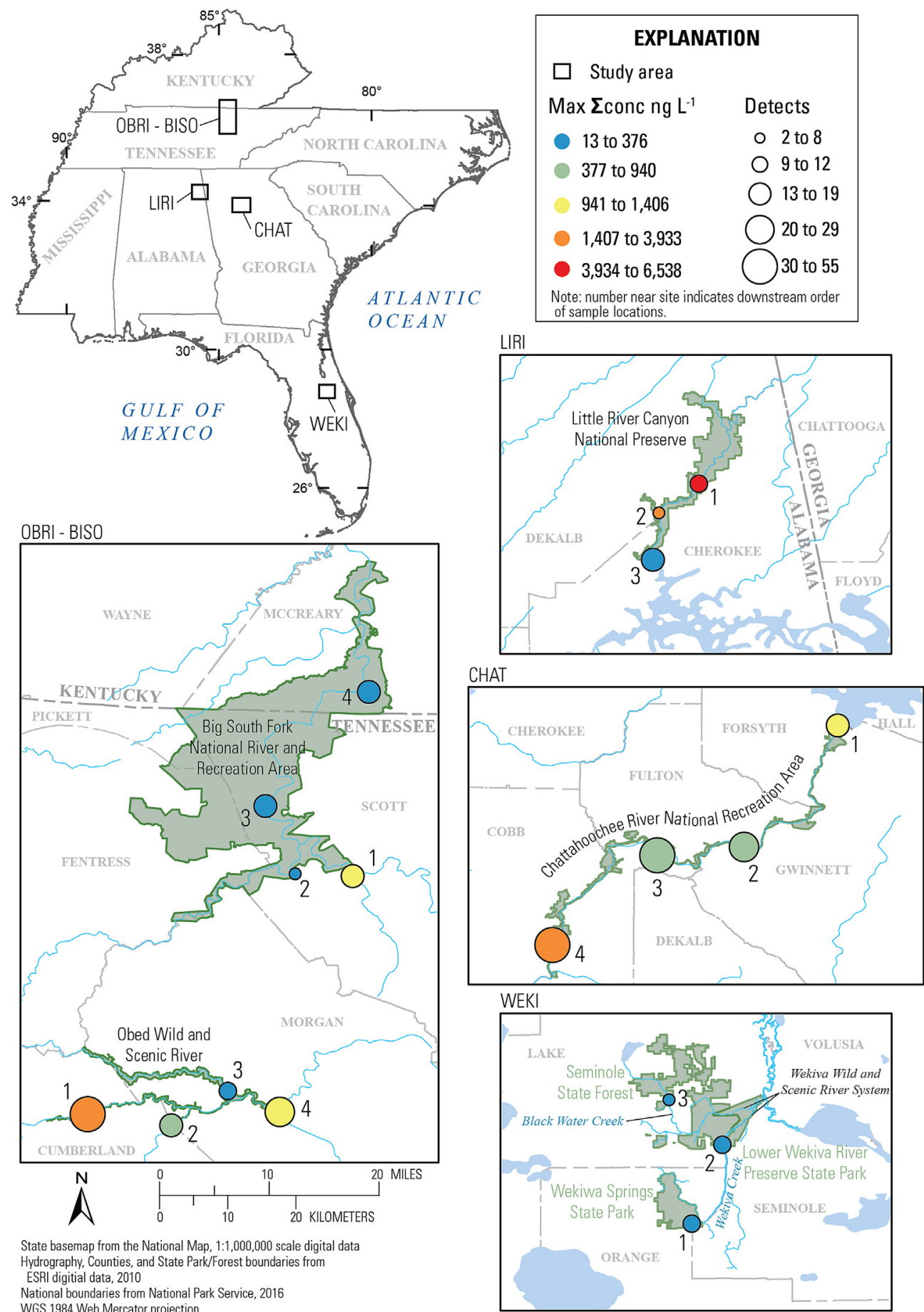

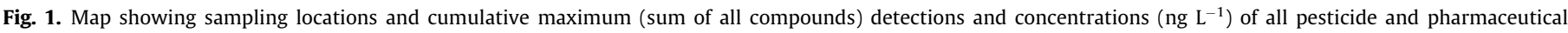
contaminants detected at least once in surface-water samples from NPS-protected southeast stream systems during $2015-2017$. Unit codes are as shown in Table 1. 

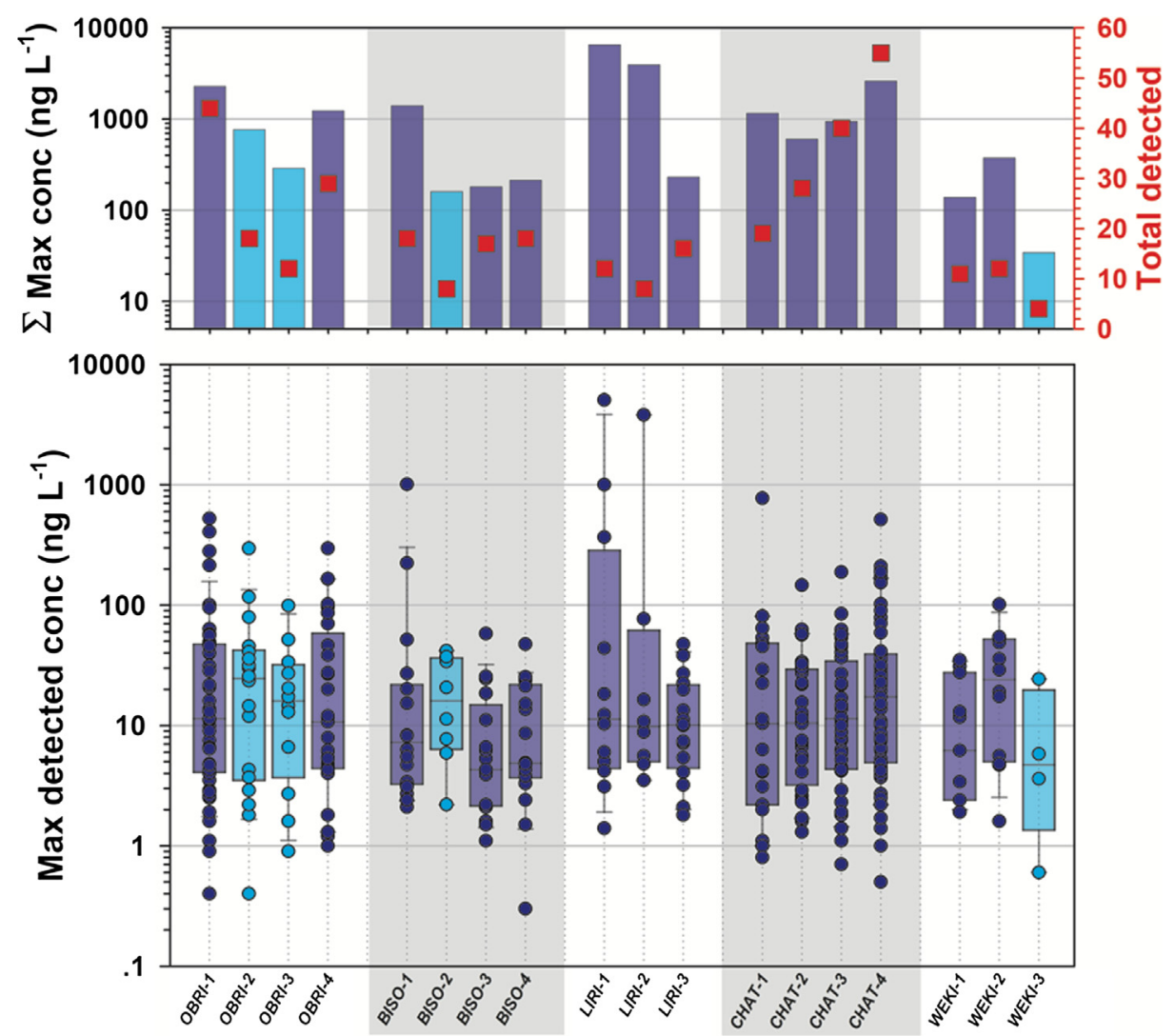

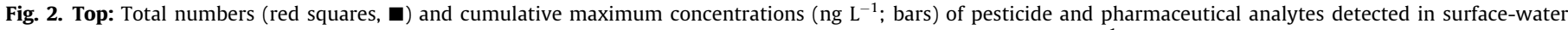

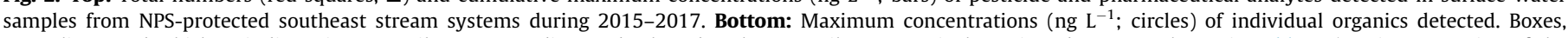

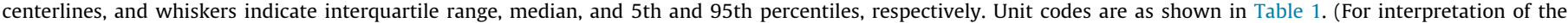
references to colour in this figure legend, the reader is referred to the web version of this article.)

and median exposure conditions, respectively, in a recent study of mixed contaminants in predominantly developed, wadeable, headwater streams within the highly urbanized Piedmont region of the southeastern US (Bradley et al., 2018a; Bradley et al., 2019).

Interestingly, a greater percentage (34\%) and often higher concentrations of pharmaceuticals were detected compared to pesticides $(19 \%)$ in NPS SER protected streams, in contrast to similar percentage detections of each (63\% and 52\%, respectively, for pharmaceuticals and pesticides) in the predominantly developed Piedmont headwater stream study (Bradley et al., 2018a; Bradley et al., 2019). The comparatively lower percentage detection of pesticides is consistent with the protective riparian buffers in four (BISO, LIRI, OBRI, WEKI) of these NPS SER stream systems and the corresponding spatial separation from common non-point (spatially diffuse) pesticide-contaminant sources, like animal and crop agriculture. Nicotine was detected at least once at every site in this study and the broad-spectrum herbicide, atrazine (or its degradate hydroxyatrazine, OIET), was detected at all but one site (Table S3b). Consistent with its pervasive detection in the floodplain-dominated Congaree National Park (Bradley et al., 2017c) and throughout the southeastern headwater streams study (Bradley et al., 2018a; Bradley et al., 2019), the anti-diabetic medicine, metformin (or its environmental metabolite, guanylurea), was detected at least once (up to more than $500 \mathrm{ng} \mathrm{L}^{-1}$; Table $3 \mathrm{~b}$ ) at all but three sites (not detected at WEKI) and in more than half of the samples (median exposure conditions) at 11 of 18 sites (Table S3c). Only nicotine and caffeine-related compounds (caffeine, dimethylxanthine) were detected at concentrations greater than $1 \mu \mathrm{g} \mathrm{L}^{-1}$ in this NPS SER study (Fig. 3; Table 3b), compared with the more than 30 compounds detected in excess of $1 \mu \mathrm{g}$
$\mathrm{L}^{-1}$ in the predominantly urban southeastern streams study (Bradley et al., 2018a; Bradley et al., 2019).

Cumulative (sum of detected) pesticide and pharmaceutical water concentrations under the estimated maximum exposure conditions ranged 34-6538 $\mathrm{ng} \mathrm{L}^{-1}$ per site (median: $685 \mathrm{ng} \mathrm{L}^{-1}$; interquartile range [IQR]: $218-1362 \mathrm{ng} \mathrm{L}^{-1}$ ) and the maximum number of analytes detected per site ranged 4-55 (median: 18; IQR: 12-26) (Figs. 1-2; Table S3b). Under the estimated median exposure conditions, cumulative (pesticide and pharmaceutical) concentrations were substantially lower than under the estimated maximum exposure conditions, ranging 4-1126 $\mathrm{ng} \mathrm{L}^{-1}$ per site (median: $67 \mathrm{ng} \mathrm{L}^{-1}$; IQR: 41-197 $\mathrm{ng} \mathrm{L}^{-1}$ ) and the number of organic compounds ranged 1-33 (median: 5; IQR: 4-12; Figures S1-S2; Table S3c).

These results demonstrate that the protected-stream ecosystems of the NPS SER are exposed to varied mixtures of pesticide and pharmaceutical contaminants, which, given their designed bioactivity, raise concerns for potential ecosystem effects. These results are consistent with the widely documented occurrence of mixed contamination in developed watersheds across the US (Bradley et al., 2017b; Bradley et al., 2018a; Bradley et al., 2019; Nowell et al., 2018; Van Metre et al., 2017) and elsewhere (e.g.; Brack et al., 2015; Busch et al., 2016; Le et al., 2017; Malaj et al., 2014; Peters et al., 2013; Posthuma et al., 2017; Rosi-Marshall and Royer, 2012; Schäfer et al., 2016) and, likewise, with the few previous reports of pesticide and pharmaceutical contaminants in protected stream systems in the US (Battaglin et al., 2018; Bradley et al., 2017c; Elliott and VanderMeulen, 2017; Weissinger et al., 2018) and elsewhere (Camacho-Muñoz et al., 2010; Gerber et al., 2016). However, the substantially lower 

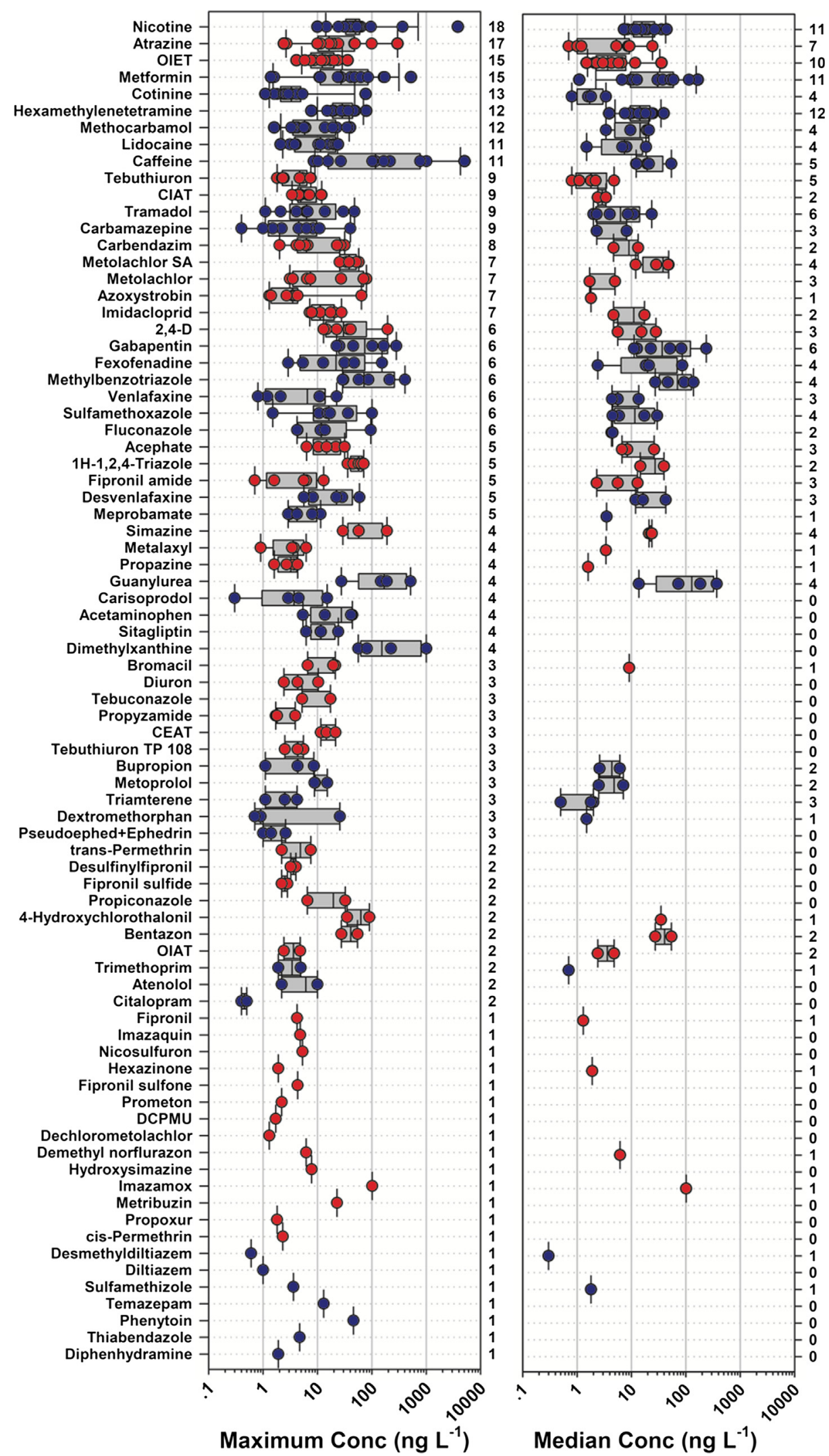

Maximum Conc $\left(\mathrm{ng} \mathrm{L}^{-1}\right)$

Median Conc (ng L ${ }^{-1}$ )

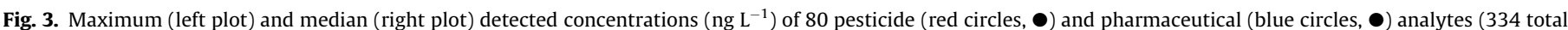

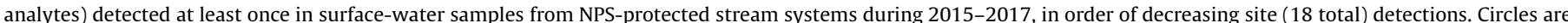

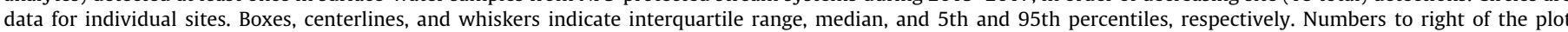

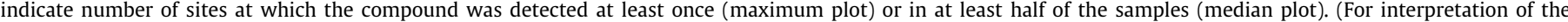
references to colour in this figure legend, the reader is referred to the web version of this article.) 
cumulative concentrations observed in this study than in the southeastern headwater stream study (maximum exposure: 1922-162346 $\mathrm{ng} \mathrm{L}^{-1}$ and 29-153 compounds per site; median exposure: 218-14099 $\mathrm{ng} \mathrm{L}^{-1}$ and 4-92 compounds per site) (Bradley et al., 2018a; Bradley et al., 2019) and the USGS-EPA national surface-water pilot study (Bradley et al., 2017b) also emphasize the benefits of protective watershed management in reducing instream exposures.

\subsection{Potential for surface-water-contaminant biological effects in protected streams}

The 334-compound analytical space assessed herein is a fraction of the putative universe of environmental contaminants, with more than 1000 pesticide (California Department of Pesticide Regulation, 2018) and 4000 pharmaceutical (Monteiro and Boxall, 2010; U.S. Food and Drug Administration, 2018) active ingredients (parent compounds) in current use and an incalculable chemical-space (Dobson, 2004) of associated metabolites and environmental degradates (Vasquez et al., 2014). Given the broad range of species, life-cycle stages, biomasses, and associated vulnerabilities that characterize southeastern stream aquatic foodwebs (Lydeard and Mayden, 1995; McKinney, 2006; Scott, 2006; Warren et al., 2000) and the intrinsic biological potency of commercially-viable pesticides and pharmaceuticals (Brodin et al., 2013; Brönmark and Hansson, 2012; Brown et al., 2014; Carter et al., 2015; Corcoran et al., 2010; Giacomini et al., 2016; Gunnarsson et al., 2008; Gunnarsson et al., 2012; Hughes et al., 2012; Kidd et al., 2014; Li, 2014; McRobb et al., 2014; Monteiro and Boxall, 2010; Painter et al., 2009; Rosi-Marshall and Royer, 2012; Schultz et al., 2011; Van Donk et al., 2015), ubiquitous detection of pesticide and pharmaceutical contaminant mixtures in NPS SER streams in this study is de facto evidence for potential molecular toxicity and possible, sub-lethal effects to non-target, aquatic organisms (Bradbury, 1994; Könemann, 1981; Russom et al., 1997; Veith et al., 1983).

The ToxCast EAR results for estimated maximum (Fig. 4; Table S7) and median (Figure S3; Table S8) exposure conditions support this conclusion. The in vitro ToxCast EAR approach informs the potential for sub-lethal effects at an observed concentration (Becker et al., 2015; Blackwell et al., 2017), provides probable effects screening consistent with traditional in vivo water-quality benchmark-based toxicity quotient (TQ) approaches (EAR $=0.001$ comparable to commonly employed $\mathrm{TQ}=0.1$ effects threshold (Corsi et al., 2019)), and supports cumulative effects ( $\sum_{\text {EAR }}$ ) estimation (CA-model (Ankley et al., 2010; Conolly et al., 2017; Judson et al., 2014; Villeneuve et al., 2014)). Although sometimes restricted only to chemicals with a common mode of action, CApredicted toxicities typically agree with observed toxicities within a factor of 2-4, regardless of recognized mode of action (Belden et al., 2007; Boobis et al., 2011; Cedergreen et al., 2008; Ermler et al., 2011; Faust et al., 2003; Rodney et al., 2013; Thrupp et al., 2018; Warne, 2003; Zhang et al., 2011). ToxCast (U.S. Environmental Protection Agency, 2019) employs primarily vertebrate cell lines to assess exposure-response thresholds for more than 9000 organic chemicals at approximately 1000 standardized, primarily molecular, endpoints (Kavlock et al., 2012; Richard et al., 2016; U.S. Environmental Protection Agency, 2018a), but does include a suite of zebrafish (ZF; Danio rerio) embryonic-exposure endpoints that provide useful models of organism-level as well as vulnerable, early-life-cycle effects in fish (Padilla et al., 2012; Truong et al., 2013). Given the diversity of organisms and respective contaminant vulnerabilities extant in southeastern stream foodwebs (Lydeard and Mayden, 1995; McKinney, 2006; Scott, 2006; Warren et al., 2000), we employed the conservative (protective) effects-screening threshold of 0.001 suggested recently (Corsi et al., 2019) as described (Bradley et al., 2019). Of the 80 pesticides and pharmaceuticals detected at least once in this study, 56\% (45) had acceptable exposure-effects relation data at the time of ToxCast access (see Table S6 for ToxCast exclusions). Under maximum exposure conditions, all but one site (WEKI-3) had at least one compound with individual EAR greater than the 0.001 effectsscreening threshold (Fig. 4), indicating, at a minimum, transient exposures with a probability of vertebrate molecular effects in NPS SER protected-stream systems. For the 49 pesticides and pharmaceuticals observed under median exposure conditions, all but one site (WEKI-3) had $\sum_{\text {EAR }}$ greater than the 0.001 effectsscreening threshold and $72 \%$ of sites (all except BISO-2, BISO-4,

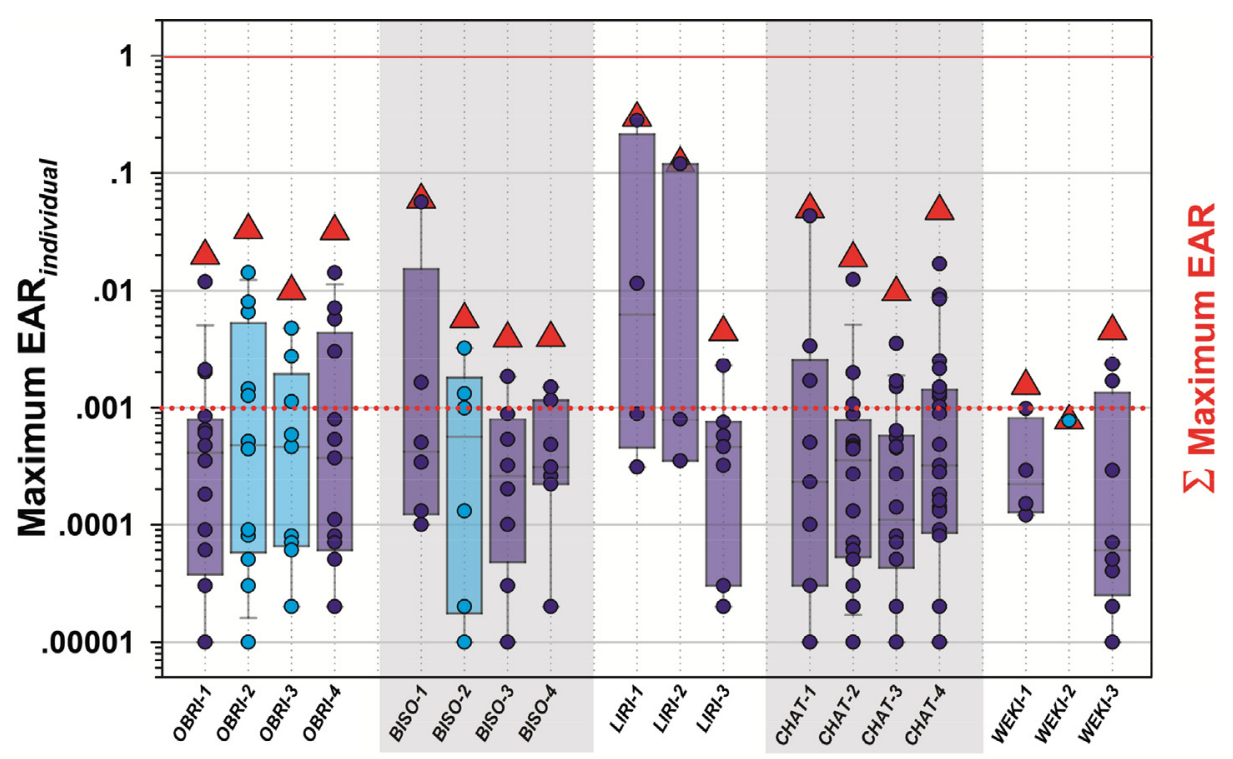

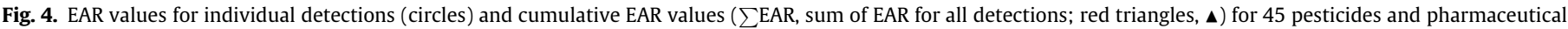

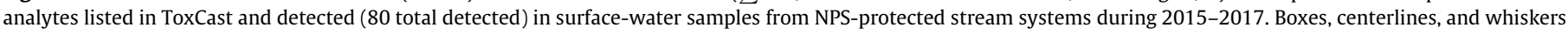

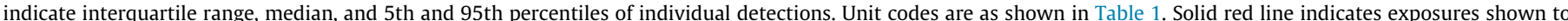

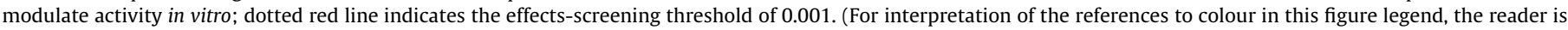
referred to the web version of this article.) 
LIRI-3, WEKI ${ }^{-1}$, WEKI-3) had at least one compound with individual EAR greater than the effects threshold (Figure S3), indicating that sites with persistent exposures with a probability of vertebrate molecular effects also were common. The ToxCast EAR results observed herein under the estimated median and maximum exposure conditions are generally lower than those reported in the southeastern headwater-stream urban-gradient study (Bradley et al., 2019). Notably, estrogenic activity, as measured by the in vitro yeast assay, was only observed at locations where at least one compound had an individual EAR greater than the effects threshold; maximum estrogenicity observed in this study was $1.72 \mathrm{ng} \mathrm{L}^{-1}$ at LIRI-2 (Table S9). Androgenic and glucogenic activities were not observed in any collected sample.

\subsection{Protected-stream sediment pesticide exposures}

Pesticides were assessed in one-time sediment samples collected in four of the study stream systems (BISO, CHAT, LIRI, OBRI), but only detected consistently at CHAT sites (Table S5). No pesticides were detected at the most upstream CHAT study site located immediately downstream of the dam discharge at Lake Lanier. Five pesticides (bifenthrin, fipronil sulfone, dithiopyr, oxadiazon, prodiamine) were detected in all downstream CHAT sample locations and at comparable concentrations. Among these, bifenthrin and fipronil sulfone (fipronil degradate) are an insecticide and insecticide-degradate, respectively, typically associated with control of fire ants and other residential pests common to the southeast US. The remaining three are common residential-use (lawn and ornamental) herbicides. The detection of residential-use pesticides (single analyte concentrations up to $55.6 \mathrm{ng} \mathrm{g}^{-1}$ prodiamine; cumulative concentrations up $71.5 \mathrm{ng} \mathrm{g}^{-1}$ ) in CHAT sediment samples is consistent with their hydrophobic character and resultant tendency to partition to sediment and with the predominantly residential land use and general lack of riparian buffers within the CHAT study reach. Notably, the toxicity of bifenthrin and fipronil sulfone to stream macroinvertebrates is well established (Cheng et al., 2017; Nowell et al., 2016; Rogers et al., 2016; Weston and Lydy, 2014) and both were observed in all downstream CHAT locations at sediment concentrations ranging 287-393 $\mathrm{ng} \mathrm{g}^{-1}$ organic carbon (OC) and 16-79 $\mathrm{ng} \mathrm{g}^{-1} \mathrm{OC}$, respectively. Multiple exceedances of the bifenthrin Threshold Effect Benchmark (TEB) of $170 \mathrm{ng} \mathrm{g}^{-1}$ OC for Hyalella azteca and the fipronil sulfone TEB of $26 \mathrm{ng} \mathrm{g}^{-1}$ OC for Chironomus species (Nowell et al., 2016) raise concerns for toxic effects to benthic organisms in the CHAT system.

\subsection{Preliminary contaminant source attribution}

While residential, lawn, and ornamental pesticides are frequently reported in wastewater in the southeast (Bradley et al., 2019) and elsewhere (Le et al., 2017; Münze et al., 2017; Sprague and Nowell, 2008), elevated occurrences in surface waters are typically attributed to spatially distributed, landscape-scale sources such as agriculture (Gilliom, 2007; Moschet et al., 2014; Ryberg and Gilliom, 2015; Shen et al., 2005; Smalling et al., 2013; Stone et al., 2014; Van Metre et al., 2017). The instream influence of such non-point sources can be substantially mitigated by establishment and maintenance of riparian buffers (Aguiar et al., 2015; Broadmeadow and Nisbet, 2004; Lerch et al., 2017; Orlinskiy et al., 2015; Turunen et al., 2019). The protective efficacy of riparian buffers, however, is undermined by hydraulic short-circuits that extend across the buffer into developed landscapes, including illicit piped discharges, agricultural tile drains, drainage ditches, or tributaries (Bereswill et al., 2012; Ghirardini and Verlicchi, 2019; Stehle et al., 2016). Land application of waste biosolids as agricultural fertilizer represents an analogous landscape-scale source of pharmaceutical contaminants to surface waters (Ghirardini and
Verlicchi, 2019; Sabourin et al., 2009), which would likewise be mitigated by riparian buffers in protected systems. However, human wastewater (wastewater treatment facility (WWTF) and septic tank) discharge is a well-documented source of elevated pharmaceutical contamination in streams (aus der Beek et al. 2016; Fatta-Kassinos et al., 2011; Loos et al., 2013; Monteiro and Boxall, 2010), including in the southeast (Bradley et al., 2017b; Bradley et al., 2016).

Four (BISO, LIRI, OBRI, WEKI) of the five stream systems included in the current study lie within protected riparian buffers (typical minimum 0.25 mile on each bank) intended to limit anthropogenic impacts to the aquatic ecosystems, including overland and shallow subsurface contaminant transport from the surrounding landscape. In such settings, fluvial inflows and visitation are notable concerns as potential sources of instream contamination (Battaglin et al., 2018; Bradley et al., 2017c; Camacho-Muñoz et al., 2010; Elliott and VanderMeulen, 2017; Gerber et al., 2016; Weissinger et al., 2018). In three (BISO, LIRI, OBRI) of these systems, lower cumulative contaminant detections and concentrations observed in tributary samples (BISO, OBRI only) than in primary-stream samples, comparable or decreasing cumulative detections and concentrations in downstream order in primary stream samples, combined with limited road access within the study reaches (except Leatherwood Ford, BISO) are consistent with fluvial inflows from upstream external sources, as suggested in other protected-area streams in the US (Battaglin et al., 2018; Bradley et al., 2017c; Elliott and VanderMeulen, 2017; Weissinger et al., 2018), Europe (Camacho-Muñoz et al., 2010), and Africa (Gerber et al., 2016). Likewise, the presence of wastewater sources, including private residential (septic) and municipal/community wastewater treatment facilities upstream of these systems (e.g., OBRI (Guyot, 2005; Knight et al., 2014)) and generally (median exposure conditions) lower detections and concentrations of pesticides (common landscape-derived, non-point contaminants) than pharmaceuticals (common wastewaterassociated, point-source contaminants) support the importance of fluvial inflows as contaminant sources to these three study reaches. Similarly, cumulative contaminant detections and concentrations in Wekiva River samples were comparable between upstream (WEKI-1) and downstream (WEKI-2) locations and generally higher than in the tributary (WEKI-3). Because the Wekiva River is spring-fed and the upstream sample location (WEKI-1) was in the spring-fed, public swimming area in Wekiva Springs State Park, the pattern of pesticide and pharmaceutical contaminants in Wekiva River water samples is consistent with groundwater-discharge and visitation-driven contaminant sources. CHAT, however, is a National Recreation Area stream that flows through the metropolitan Atlanta urban center with predominantly private land ownership on both banks and intermittent riparian protection in isolated park properties (typically on one bank) distributed throughout the study reach. Numerous sources of anthropogenic contamination, including residential waterfront lawns and gardens and municipal WWTF on tributaries, are well-documented within the study reach (Bradley et al., 2019; Calhoun et al., 2003; Frick and Zaugg, 2003; Frick et al., 1998; Glassmeyer et al., 2005; Gregory and Frick, 2000; Hinck et al., 2007; Hinck et al., 2008).

\section{Conclusions}

Importantly, 76\% (2 54 ) of the pesticides and pharmaceuticals assessed in this study were not detected. However, 80 pesticides and pharmaceuticals were detected across all sites, with detection frequencies for individual compounds ranging up to $100 \%$ (18) of sites for nicotine (median: 3 sites; 17\%). Frequent detections of 
pesticide and pharmaceutical contaminant mixtures and common exceedance of the 0.001 EAR effects-screening threshold (Corsi et al., 2019) in NPS SER protected-stream systems raise concerns for potential adverse effects to aquatic and associated terrestrial foodwebs and illustrate the opportunity for improved direct and indirect management actions. Visitors and proximal property owners are often heavily vested in preserving the health and beauty of NPS SER protected streams, potentially increasing the efficacy of public outreach efforts, particularly those posted at stream access points. Accordingly, widespread dissemination of these results and the findings of other NPS studies using accessible language is indicated. For example, in light of the global Type II diabetes epidemic, communicating the widespread occurrence and probable adverse effects of metformin contamination in protected streams as "Drugs to treat diabetes have been found in this stream. These medicines affect fish as well as humans" is likely to be instantly relatable for many park visitors. As suggested earlier (Battaglin et al., 2018), because many human-use pharmaceuticals are excreted primarily in urine (e.g., metformin), modification of current "Leave No Trace Principles" on backcountry human waste disposal (Leave No Trace Center for Outdoor Ethics, 2019) to provide comparable emphasis on minimizing urination impacts is appropriate. The results of this reconnaissance indicate that fluvial and groundwater inflows from up-gradient external contaminant sources are important drivers of in-stream concentrations of pesticides and pharmaceuticals, suggesting the need for increased engagement with potential up-gradient contributors including waterfront property owners and municipal WWTF.

\section{Acknowledgments}

The USGS Toxic Substances Hydrology Program and the USGSNPS Water Quality Partnership Program supported this research. The authors thank Lakyn Sanders of the USGS for assistance with in vitro bioassays and Anna McKee of the USGS and anonymous journal referees for their reviews. The use of trade, firm, or product names is for descriptive purposes only and does not imply endorsement by the U.S. Government. This report contains CAS Registry Numbers, which is a Registered Trademark of the American Chemical Society. CAS recommends the verification of the CASRNs through CAS Client ServicesSM.

\section{Appendix A. Supplementary data}

Supplementary data to this article can be found online at https://doi.org/10.1016/j.scitotenv.2019.135431.

\section{References}

Ackerman, L., Schwindt, A., Massey Simonich, S., Koch, D., Blett, T., Schreck, C., et al. 2008. Atmospherically deposited PBDEs, pesticides, PCBs, and PAHs in Western U.S. National Park fish: concentrations and consumption guidelines. Environ. Sci. Technol. 42, 2334-2341.

Aguiar, T.R., Bortolozo, F.R., Hansel, F.A., Rasera, K., Ferreira, M.T., 2015. Riparian buffer zones as pesticide filters of no-till crops. Environ. Sci. Pollut. Res. 22, 10618-10626.

Altenburger, R., Scholz, S., Schmitt-Jansen, M., Busch, W., Escher, B.I., 2012. Mixture toxicity revisited from a toxicogenomic perspective. Environ. Sci. Technol. 46 2508-2522.

Altenburger, R., Backhaus, T., Boedeker, W., Faust, M., Scholze, M., 2013. Simplifying complexity: mixture toxicity assessment in the last 20 years. Environ. Toxicol. Chem. 32, 1685-1687.

Ankley, G.T., Bennett, R.S., Erickson, R.J., Hoff, D.J., Hornung, M.W., Johnson, R.D. et al., 2010. Adverse outcome pathways: a conceptual framework to support ecotoxicology research and risk assessment. Environ. Toxicol. Chem. 29, 730741.

ASTM International. ASTM D7729-12(2018)e1, 2018. Standard Practice for Determining and Expressing Precision of Measurement Results, in the Analysis of Water, as Relative Standard Deviation, Utilizing DQCALC Software. ASTM D7729-12 e1, 5 . aus der Beek, T., Weber, F.-A., Bergmann, A., Hickmann, S., Ebert, I., Hein, A., et al., 2016. Pharmaceuticals in the environment-Global occurrences and perspectives. Environ. Toxicol. Chem. 35, 823-835.

Battaglin, W.A., Smalling, K.L., Anderson, C., Calhoun, D., Chestnut, T., Muths, E., 2016. Potential interactions among disease, pesticides, water quality and adjacent land cover in amphibian habitats in the United States. Sci. Total Environ. 566-567, 320-332.

Battaglin, W.A., Bradley, P.M., Iwanowicz, L.R., Journey, C.A., Walsh, H.L., Blazer, V.S., 2018a. Pharmaceuticals, hormones, pesticides, and other bioactive contaminants in water, sediment, and tissue from Rocky Mountain National Park, 2012-2013. Sci. Total Environ. 643, 651-673.

Becker, R.A., Friedman, K.P., Simon, T.W., Marty, M.S., Patlewicz, G., Rowlands, J.C., 2015. An exposure: activity profiling method for interpreting high-throughput screening data for estrogenic activity-Proof of concept. Regul. Toxicol. Pharm. 71, 398-408.

Belden, J.B., Gilliom, R.J., Lydy, M.J., 2007. How well can we predict the toxicity of pesticide mixtures to aquatic life?. Integr. Environ. Assess. Manage. 3, 364-372.

Bereswill, R., Golla, B., Streloke, M., Schulz, R., 2012. Entry and toxicity of organic pesticides and copper in vineyard streams: Erosion rills jeopardise the efficiency of riparian buffer strips. Agric. Ecosyst. Environ. 146, 81-92.

Blackwell, B.R., Ankley, G.T., Corsi, S.R., De Cicco, L.A., Houck, K.A., Judson, R.S., et al., 2017. An "EAR" on environmental surveillance and monitoring: a case study on the use of exposure-activity ratios (EARs) to prioritize sites, chemicals, and bioactivities of concern in Great Lakes waters. Environ. Sci. Technol. 51, 87138724.

Boobis, A., Budinsky, R., Collie, S., Crofton, K., Embry, M., Felter, S., et al., 2011. Critical analysis of literature on low-dose synergy for use in screening chemical mixtures for risk assessment. Crit. Rev. Toxicol. 41, 369-383.

Boström, M.L., Berglund, O., 2015. Influence of pH-dependent aquatic toxicity of ionizable pharmaceuticals on risk assessments over environmental pH ranges. Water Res. 72, 154-161.

Brack, W., Altenburger, R., Schüürmann, G., Krauss, M., López Herráez, D., van Gils, J., et al., 2015. The solutions project: challenges and responses for present and future emerging pollutants in land and water resources management. Sci. Total Environ. 503-504, 22-31.

Bradbury, S.P., 1994. Predicting modes of toxic action from chemical structure: an overview. SAR OSAR Environ. Res. 2, 89-104.

Bradley, P., Journey, C., Romanok, K.M. Concentrations of Pesticides, Pharmaceuticals, Organic Waste Indicators, and Volatile Organic Chemical Contaminants and Their Predicted Effects Potential in Wadeable Southeastern USA Streams. U.S. Geological Survey data release Available from <https://doi. org/10.5066/P9HRZVQ5>.

Bradley, P., Journey, C., Romanok, K. Concentrations of Bioactive Organic Contaminants in Water and Sediment and Rates of Contaminant Biodegradation in Sediment at Congaree National Park, USA 2013-15. U.S. Geological Survey data release. Available from <https://doi.org/10.5066/F7FB513R>.

Bradley, P.M., Journey, C.A., Button, D.T., Carlisle, D.M., Clark, J.M., Mahler, B.J., et al., 2016. Metformin and Other Pharmaceuticals Widespread in Wadeable Streams of the Southeastern United States. Environ. Sci. Technol. Lett. 3, 243-249.

Bradley, P.M., Battaglin, W.A., Clark, J.M., Henning, F., Hladik, M.L., Iwanowicz, L.R., et al., 2017c. Widespread occurrence and potential for biodegradation of bioactive contaminants in Congaree National Park, USA. Environ. Toxicol. Chem. 36, 3045-3056.

Bradley, P., Journey, C., Romanok, K., Barber, L., Buxton, H.T., Foreman, W.T., et al., 2017b. Expanded target-chemical analysis reveals extensive mixed-organiccontaminant exposure in USA streams. Environ. Sci. Technol. 51, 4792-4802.

Bradley, P.M., Kolpin, D.W., Romanok, K.M., Smalling, K.L., Focazio, M.J., Brown, J.B. et al., 2018b. Reconnaissance of mixed organic and inorganic chemicals in private and public supply tapwaters at selected residential and workplace sites in the United States. Environ. Sci. Technol.

Bradley, P.M., Journey, C.A., Berninger, J.P., Button, D.T., Clark, J.M., Corsi, S.R., et al. 2019. Mixed-chemical exposure and predicted effects potential in Wadeable Southeastern USA streams. Sci. Total Environ. 655, 70-83.

Broadmeadow, S., Nisbet, T.R., 2004. The effects of riparian forest management on the freshwater environment: a literature review of best management practice. Hydrol. Earth Syst. Sci. Discuss. 8, 286-305.

Brodin, T., Fick, J., Jonsson, M., Klaminder, J., 2013. Dilute concentrations of a psychiatric drug alter behavior of fish from natural populations. Science 339, 814-815.

Brönmark, C., Hansson, L.-A., 2012. Aquatic Chemical Ecology: New Directions and Challenges for the Future. Chemical Ecology in Aquatic Systems. Oxford University Press, Oxford, pp. 272-278.

Brown, A.R., Gunnarsson, L., Kristiansson, E., Tyler, C.R., 2014. Assessing variation in the potential susceptibility of fish to pharmaceuticals, considering evolutionary differences in their physiology and ecology. Phil. Trans. R. Soc. Lond. B: Biol. Sci. 369, 20130576.

Busch, W., Schmidt, S., Kühne, R., Schulze, T., Krauss, M., Altenburger, R., 2016. Micropollutants in European rivers: a mode of action survey to support the development of effect-based tools for water monitoring. Environ. Toxicol. Chem. 35, 1887-1899.

Calhoun, D.L., Frick, E.A., Buell, G.R., 2003. Effects of urban development on nutrient loads and streamflow, upper Chattahoochee River basin, Georgia, 1976-2001. Proceedings of the 2003 Georgia Water Resources Conference.

California Department of Pesticide Regulation. Chemical Ingredients Queries. June 29, 2018. Available from <https://www.cdpr.ca.gov/docs/chemical/monster. htm>. 
Camacho-Muñoz, M.D., Santos, J.L., Aparicio, I., Alonso, E., 2010. Presence of pharmaceutically active compounds in Doñana Park (Spain) main watersheds. J. Hazard. Mater. 177, 1159-1162.

Carter, L.J., Williams, M., Böttcher, C., Kookana, R.S., 2015. Uptake of pharmaceuticals influences plant development and affects nutrient and hormone homeostases. Environ. Sci. Technol. 49, 12509-12518.

Cedergreen, N., Christensen, A.M., Kamper, A., Kudsk, P., Mathiassen, S.K., Streibig, J. C., et al., 2008. A review of independent action compared to concentration addition as reference models for mixtures of compounds with different molecular target sites. Environ. Toxicol. Chem. 27, 1621-1632.

Cheng, F., Li, H., Qi, H., Han, Q., You, J., 2017. Contribution of pyrethroids in large urban rivers to sediment toxicity assessed with benthic invertebrates Chironomus dilutus: A case study in South China. Environ. Toxicol. Chem. 36, 3367-3375.

Childress, C., Foreman, W., Conner, B., Maloney, T. 1999. New reporting procedures based on long-term method detection levels and some considerations for interpretations of water-quality data provided by the U.S. Geological Survey National Water Quality Laboratory. U.S. Geological Survey Open-File Report 99193, 19.

Conley, J., Evans, N., Cardon, M., Rosenblum, L., Iwanowicz, L., Hartig, P., et al., 2017. Occurrence and in vitro bioactivity of estrogen, androgen, and glucocorticoid compounds in a nationwide screen of United States stream waters. Environ. Sci. Technol. 51, 4781-4791.

Conolly, R.B., Ankley, G.T., Cheng, W., Mayo, M.L., Miller, D.H., Perkins, E.J., et al., 2017. Quantitative adverse outcome pathways and their application to predictive toxicology. Environ. Sci. Technol. 51, 4661-4672.

Corcoran, J., Winter, M.J., Tyler, C.R., 2010. Pharmaceuticals in the aquatic environment: a critical review of the evidence for health effects in fish. Crit. Rev. Toxicol. 40, 287-304.

Corsi, S.R., De Cicco, L.A., Villeneuve, D.L., Blackwell, B.R., Fay, K.A., Ankley, G.T., et al., 2019. Prioritizing chemicals of ecological concern in Great Lakes tributaries using high-throughput screening data and adverse outcome pathways. Sci. Total Environ. 686, 995-1009.

Daughton, C., Brooks, B., 2011. Active pharmaceutical ingredients and aquatic organisms. In: Beyer, W., Meador, J. (Eds.), Environmental Contaminants in Biota: Interpreting Tissue Concentrations. CRC Press, Boca Raton, FL, pp. 288348

Daughton, C., Ternes, T., 1999. Pharmaceuticals and personal care products in the environment: agents of subtle change? Environ. Health Perspect. 107, 907938.

De Cicco, L., Corsi, S.R., Villeneuve, D., Blackwell, B.R., Ankley, G.T., 2018. toxEval: Evaluation of measured concentration data using the ToxCast high-throughput screening database or a user-defined set of concentration benchmarks. $\mathrm{R}$ package version 1.0.0. Available from <https://owi.usgs.gov/R/gran.html> (accessed 1.08.18.).

Dobson, C.M., 2004. Chemical space and biology. Nature 432, 824-828.

Dong, B., Kahl, A., Cheng, L., Vo, H., Ruehl, S., Zhang, T., et al., 2015. Fate of trace organics in a wastewater effluent dependent stream. Sci. Total Environ. 518, 479-490.

Egler, A., Risch, M., Alvarez, D., Bradley, P., 2009-11.. Organic wastewater compounds in water and sediment in and near restored wetlands. Great Marsh, Indiana Dunes National Lakeshore, 52.

Elliott, S.M., VanderMeulen, D.D., 2017. A regional assessment of chemicals of concern in surface waters of four Midwestern United States national parks. Sci. Total Environ. 579, 1726-1735.

Ermler, S., Scholze, M., Kortenkamp, A., 2011. The suitability of concentration addition for predicting the effects of multi-component mixtures of up to 17 anti-androgens with varied structural features in an in vitro AR antagonist assay. Toxicol. Appl. Pharmacol. 257, 189-197.

Fatta-Kassinos, D., Vasquez, M., Kümmerer, K., 2011. Transformation products of pharmaceuticals in surface waters and wastewater formed during photolysis and advanced oxidation processes-degradation, elucidation of byproducts and assessment of their biological potency. Chemosphere 85, 693-709.

Faust, M., Altenburger, R., Backhaus, T., Blanck, H., Boedeker, W., Gramatica, P., et al., 2003. Joint algal toxicity of 16 dissimilarly acting chemicals is predictable by the concept of independent action. Aquat. Toxicol. 63, 43-63.

Focazio, M., Kolpin, D.W., Barnes, K., Furlong, E.T., Meyer, M., Zaugg, S., et al., 2008. A national reconnaissance of pharmaceuticals and other organic wastewater contaminants in the United States-II. Untreated drinking water sources. Sci. Total Environ. 402, 201-216.

Foresta, R.A., 2013. America's national parks and their keepers. RFF Press.

Frick, E., Zaugg, S., 2003. Organic wastewater contaminants in the Upper Chattahoochee River basin, Georgia, 1999-2002. In: Hatcher K, editor. 2003 Georgia Water Resources Conference, University of Georgia, p. 7.

Frick, E.A., Hiipe, D.J., Buell, G.R., Couch, C.A., Hopkins, E.H., Wangsness, D.J., et al., 1998. Water quality in the Apalachicola-Chattahoochee-Flint River basin, Georgia, Alabama, and Florida, 1992-95. 1164.

Furlong, E., Noriega, M., Kanagy, C., Kanagy, L., Coffey, L., Burkhardt, M. 2014 Methods of the National Water Quality Laboratory. Chapter B10. Determination of human-use pharmaceuticals in filtered water by direct aqueous injectionhigh-performance liquid chromatography/tandem mass spectrometry. U.S. Geological Survey Techniques and Methods. Book 5. Laboratory Analysis. Chap. B10: 49 .

Gaston, K.J., Jackson, S.F., Cantú-Salazar, L., Cruz-Piñón, G., 2008. The Ecological Performance of Protected Areas. Annu. Rev. Ecol. Evol. Syst. 39, 93113.
U.S. Geological Survey. 2019. National Water Information System (NWIS)-Web interface. Available from <http://doi.org/10.5066/F7P55KJN> (accessed 12.01.19.).

Gerber, R., Smit, N.J., Van Vuren, J.H.J., Nakayama, S.M.M., Yohannes, Y.B., Ikenaka, Y., et al., 2016. Bioaccumulation and human health risk assessment of DDT and other organochlorine pesticides in an apex aquatic predator from a premier conservation area. Sci. Total Environ. 550, 522-533.

Ghirardini, A., Verlicchi, P., 2019. A review of selected microcontaminants and microorganisms in land runoff and tile drainage in treated sludge-amended soils. Sci. Total Environ. 655, 939-957.

Giacomini, A.C.V., Abreu, M.S., Giacomini, L.V., Siebel, A.M., Zimerman, F.F., Rambo, C.L., et al., 2016. Fluoxetine and diazepam acutely modulate stress inducedbehavior. Behav. Brain Res. 296, 301-310.

Gilliom, R.J., 2007. Pesticides in US streams and groundwater. Environ. Sci. Technol. 41, 3408-3414.

Glassmeyer, S., Furlong, E., Kolpin, D., Cahill, J., Zaugg, S., Werner, S., et al., 2005 Transport of chemical and microbial compounds from known wastewater discharges: potential for use as indicators of human fecal contamination. Environ. Sci. Technol. 39, 5157-5169.

Gregory, M.B., Frick, E.A., 1994. Fecal-coliform bacteria concentrations in streams of the Chattahoochee River National Recreation Area Metropolitan Atlanta Georgia, May-October 1994 and 1995, 4139.

Gunnarsson, L., Jauhiainen, A., Kristiansson, E., Nerman, O., Larsson, D.G.J., 2008 Evolutionary conservation of human drug targets in organisms used for environmental risk assessments. Environ. Sci. Technol. 42, 5807-5813.

Gunnarsson, L., Kristiansson, E., Larsson, D.J., 2012. Environmental comparative pharmacology: theory and application. Human Pharmaceuticals in the Environment Springer, 85-108.

Guyot, J., 2005. Restoration of the endangered Cumberland elktoe (Alasmidonta atropurpurea) and Cumberland bean (Villosa trabalis) (Bivalvia: Unionidae) in the Big South Fork National River and Recreation Area, Tennessee and Kentucky. Fisheries and Wildlife Sciences. Master of Science Virginia Polytechnic Institute and State University. p. 146.

Hinck, J.E., Blazer, V.S., Denslow, N.D., Echols, K.R., Gale, R.W., Wieser, C., et al., 2008 Chemical contaminants, health indicators, and reproductive biomarker responses in fish from rivers in the Southeastern United States. Sci. Total Environ. 390, 538-557.

Hinck, J.E., Blazer, V., Denslow, N.D., Echols, K.R., Gale, R.W., May, T.W., et al. 2007 Biomonitoring of Environmental Status and Trends (BEST) Program: Environmental contaminants, health indicators, and reproductive biomarkers in fish from the Mobile, Apalachicola-Chattahoochee-Flint, Savannah, and Pee Dee River Basins U.S. Geological Survey Scientific Investigations Report 20075176.

Hladik, M.L., McWayne, M.M. 2012. Methods of analysis-Determination of pesticides in sediment using gas chromatography/mass spectrometry. U.S. Geological Survey Techniques and Methods. Book 5. Laboratory Analysis. Chap C3: 28.

Hughes, S.R., Kay, P., Brown, L.E., 2012. Global synthesis and critical evaluation of pharmaceutical data sets collected from river systems. Environ. Sci. Technol. 47, 661-677.

Jenkins, C.N., Van Houtan, K.S., Pimm, S.L., Sexton, J.O., 2015. US protected lands mismatch biodiversity priorities. Proc. Natl. Acad. Sci. 112, 5081-5086.

Joppa, L.N., Loarie, S.R., 2008. In: Proceedings of the National Academy of Sciences, pp. 6673-6678.

Judson, R., Houck, K., Martin, M., Knudsen, T., Thomas, R.S., Sipes, N., et al., 2014. In vitro and modelling approaches to risk assessment from the US Environmental Protection Agency ToxCast programme. Basic Clin. Pharmacol. Toxicol. 115, 6976.

Kavlock, R., Chandler, K., Houck, K., Hunter, S., Judson, R., Kleinstreuer, N., et al., 2012. Update on EPA's ToxCast program: providing high throughput decision support tools for chemical risk management. Chem. Res. Toxicol. 25, $1287-$ 1302.

Kidd, K.A., Paterson, M.J., Rennie, M.D., Podemski, C.L., Findlay, D.L., Blanchfield, P.J. et al., 2014. Direct and indirect responses of a freshwater food web to a potent synthetic oestrogen. Phil. Trans. R. Soc. B: Biol. Sci. 369, 20130578.

Knight, R.R., Wolfe, W.J., Law, G.S., 2014:. Hydrologic data for the Obed River watershed. Tennessee 1102, 34

Kolpin, D., Furlong, E., Meyer, M., Thurman, E., Zaugg, S., Barber, L., et al., 2002 Pharmaceuticals, hormones and other organic wastewater contaminants in U.S. streams, 1999-2000: a national synthesis. Environ. Sci. Technol. 36, 12021211.

Könemann, H., 1981. Quantitative structure-activity relationships in fish toxicity studies Part 1: Relationship for 50 industrial pollutants. Toxicology 19, 209221.

Kortenkamp, A., Backhaus, T., Faust, M. 2009. State of the art report on mixture toxicity. Contract 70307/2007485103, 94-103.

Landers, D., Simonich, S., Jaffe, D., Geiser, L., Campbell, D., Schwindt, A., et al., 2008 The Fate, Transport, and Ecological Impacts of Airborne Contaminants in Western National Parks (USA). 350.

Landewe, R., 2008. Scope of Contaminants of Emerging Concern in National Parks. 22

Le, T.D.H., Scharmüller, A., Kattwinkel, M., Kühne, R., Schüürmann, G., Schäfer, R.B., 2017. Contribution of waste water treatment plants to pesticide toxicity in agriculture catchments. Ecotoxicol. Environ. Saf. 145, 135-141.

Leave No Trace Center for Outdoor Ethics. 2019. Leave No Trace. Available from <https://lnt.org> (accessed 24.07.). 
Lerch, R.N., Lin, C.H., Goyne, K.W., Kremer, R.J., Anderson, S.H., 2017. Vegetative Buffer Strips for Reducing Herbicide Transport in Runoff: Effects of Buffer Width, Vegetation, and Season. JAWRA J. Am. Water Resour. Assoc. 53, 667-683.

Li, W.C., 2014. Occurrence, sources, and fate of pharmaceuticals in aquatic environment and soil. Environ. Pollut. 187, 193-201.

Li, S., Villeneuve, D.L., Berninger, J.P., Blackwell, B.R., Cavallin, J.E., Hughes, M.N., et al., 2017. An integrated approach for identifying priority contaminant in the Great Lakes Basin-Investigations in the Lower Green Bay/Fox River and Milwaukee Estuary areas of concern. Sci. Total Environ. 579, 825-837.

Loos, R., Carvalho, R., António, D.C., Comero, S., Locoro, G., Tavazzi, S., et al., 2013. EU-wide monitoring survey on emerging polar organic contaminants in wastewater treatment plant effluents. Water Res. 47, 6475-6487.

Lydeard, C., Mayden, R.L., 1995. A diverse and endangered aquatic ecosystem of the Southeast United States. Conserv. Biol. 9, 800-805.

Malaj, E., von der Ohe, P.C., Grote, M., Kühne, R., Mondy, C.P., Usseglio-Polatera, P. et al., 2014. Organic chemicals jeopardize the health of freshwater ecosystems on the continental scale. Proc. Natl. Acad. Sci. 111, 9549-9554.

Mann, R.M., Hyne, R.V., Choung, C.B., Wilson, S.P., 2009. Amphibians and agricultural chemicals: review of the risks in a complex environment. Environ. Pollut. 157, 2903-2927.

Mast, M., Foreman, W., Skaates, S., 2006. Organochlorine compounds and currentuse pesticides in snow and lake sediment in Rocky Mountain National Park, Colorado, and Glacier National Park, Montana, 2002-03. U.S. Geological Survey Scientific Investigations Report 2006-5119, 54

Mast, M., Foreman, W., Skaates, S., 2007. Current-use pesticides and organchlorine compounds in precipitation and lake sediment from two high-elevation National Parks in the Western United States. Arch. Environ. Con. Toxicol. 52, 294-305.

McKinney, M.L., 2006. Urbanization as a major cause of biotic homogenization. Biol. Conserv. 127, 247-260.

McRobb, F.M., Sahagún, V., Kufareva, I., Abagyan, R., 2014. In silico analysis of the conservation of human toxicity and endocrine disruption targets in aquatic species. Environ. Sci. Technol. 48, 1964-1972.

Monteiro, S.C., Boxall, A.B., 2010. Occurrence and fate of human pharmaceuticals in the environment. Rev.Environ. Con. Toxicol. Springer, 53-154.

Moretto, A., Bachman, A., Boobis, A., Solomon, K.R., Pastoor, T.P., Wilks, M.F., et al., 2017. A framework for cumulative risk assessment in the 21st century. Crit. Rev. Toxicol. 47, 85-97.

Moschet, C., Wittmer, I., Simovic, J., Junghans, M., Piazzoli, A., Singer, H., et al., 2014 How a complete pesticide screening changes the assessment of surface wate quality. Environ. Sci. Technol. 48, 5423-5432.

Münze, R., Hannemann, C., Orlinskiy, P., Gunold, R., Paschke, A., Foit, K., et al., 2017. Pesticides from wastewater treatment plant effluents affect invertebrate communities. Sci. Total Environ. 599-600, 387-399.

Norton, S.B., Rodier, D.J., van der Schalie, W.H., Wood, W.P., Slimak, M.W., Gentile, J. H., 1992. A framework for ecological risk assessment at the EPA. Environ. Toxicol. Chem. 11, 1663-1672.

Nowell, L.H., Crawford, C.G., Gilliom, R.J., Nakagaki, N., Stone, W.W., Thelin, G.P. et al., 2009. Regression models for explaining and predicting concentrations of organochlorine pesticides in fish from streams in the United States. Environ. Toxicol. Chem. 28, 1346-1358.

Nowell, L.H., Norman, J.E., Moran, P.W., Martin, J.D., Stone, W.W., 2014. Pesticide toxicity index-A tool for assessing potential toxicity of pesticide mixtures to freshwater aquatic organisms. Sci. Total Environ. 476, 144-157.

Nowell, L.H., Norman, J.E., Ingersoll, C.G., Moran, P.W., 2016. Development and application of freshwater sediment-toxicity benchmarks for currently used pesticides. Sci. Total Environ. 550, 835-850.

Nowell, L.H., Moran, P.W., Schmidt, T.S., Norman, J.E., Nakagaki, N., Shoda, M.E. et al., 2018. Complex mixtures of dissolved pesticides show potential aquatic toxicity in a synoptic study of Midwestern US streams. Sci. Total Environ. 613614, 1469-1488.

Orlinskiy, P., Münze, R., Beketov, M., Gunold, R., Paschke, A., Knillmann, S., et al., 2015. Forested headwaters mitigate pesticide effects on macroinvertebrate communities in streams: mechanisms and quantification. Sci. Total Environ. $524-525,115-123$.

Painter, M., Buerkley, M., Julius, M., Vajda, A., Norris, D., Barber, L., et al., 2009. Antidepressants at environmentally relevant concentrations affect predator avoidance behavior of larval fathead minnows (Pimephales promelas). Environ. Toxicol. Chem. 28, 2677-2684.

Palomo, I., Martín-López, B., Potschin, M., Haines-Young, R., Montes, C., 2013. National Parks, buffer zones and surrounding lands: Mapping ecosystem service flows. Ecosyst. Serv, 4, 104-116.

Peters, K., Bundschuh, M., Schäfer, R., 2013. Review on the effects of toxicants on freshwater ecosystem functions. Environ. Pollut. 180, 324-329.

Posthuma, L., Brown, C., De Zwart, D., Diamond, J., Dyer, S.D. Holmes, C.M., et al. 2017. Prospective mixture risk assessment and management prioritizations fo river catchments with diverse land uses. Environ. Toxicol. Chem.

Radeloff, V.C., Hammer, R.B., Stewart, S.I., Fried, J.S., Holcomb, S.S., McKeefry, J.F. 2005. The wildland-urban interface in the United States. Ecol. Appl. 15, 799 805.

Radeloff, V.C., Stewart, S.I., Hawbaker, T.J., Gimmi, U., Pidgeon, A.M., Flather, C.H. et al., 2010. Housing growth in and near United States protected areas limits their conservation value. Proc. Natl. Acad. Sci. 107, 940-945.

Richard, A.M., Judson, R.S., Houck, K.A., Grulke, C.M., Volarath, P., Thillainadarajah, I. et al., 2016. ToxCast chemical landscape: paving the road to 21st century toxicology. Chem. Res. Toxicol. 29, 1225-1251.
Rodier, D., Norton, S., 1992. Framework for ecological risk assessment. Environmental Protection Agency, EPA-630/R-92/001.

Rodney, S.I., Teed, R.S., Moore, D.R., 2013. Estimating the toxicity of pesticide mixtures to aquatic organisms: a review. Hum. Ecol. Risk Assess.: An Int. J. 19, $1557-1575$

Rogers, H.A., Schmidt, T.S., Dabney, B.L., Hladik, M.L., Mahler, B.J., Van Metre, P.C., 2016. Bifenthrin causes trophic cascade and altered insect emergence in mesocosms: implications for small streams. Environ. Sci. Technol. 50, 1197411983.

Romanok, K.M., Bradley, P.M. 2019. Pesticides and Pharmaceutical Exposure Data for Select Protected Streams of the US National Park Service Southeast Region 2013-2015. U.S. Geological Survey data release. Available from <https://doi.org/ 10.5066/P918VCBQ>.

Rosi-Marshall, E., Kincaid, D., Bechtold, H., Royer, T., Rojas, M., Kelly, J., 2013. Pharmaceuticals suppress algal growth and microbial respiration and alter bacterial communities in stream biofilms. Ecol. Appl. 23, 583-593.

Rosi-Marshall, E.J., Royer, T.V., 2012. Pharmaceutical compounds and ecosystem function: an emerging research challenge for aquatic ecologists. Ecosystems 15, 867-880.

Russom, C.L., Bradbury, S.P., Broderius, S.J., Hammermeister, D.E., Drummond, R.A., 1997. Predicting modes of toxic action from chemical structure: acute toxicity in the fathead minnow (Pimephales promelas). Environ. Toxicol. Chem. 16, 948-967.

Ryberg, K.R., Vecchia, A.V., Gilliom, R.J., Martin, J.D. 2014. Pesticide Trends in Major Rivers of the United States, 1992-2010 U.S. Geological Survey Scientific Investigations Report 2014-5135: 63

Ryberg, K.R., Gilliom, R.J., 2015. Trends in pesticide concentrations and use for major rivers of the United States. Sci. Total Environ. 538, 431-444.

Sabourin, L., Beck, A., Duenk, P.W., Kleywegt, S., Lapen, D.R., Li, H., et al., 2009. Runoff of pharmaceuticals and personal care products following application of dewatered municipal biosolids to an agricultural field. Sci. Total Environ. 407, 4596-4604.

Sandstrom, M.W., Kanagy, L.K., Anderson, C.A., Kanagy, C.J., 2016. Methods of the National Water Quality Laboratory. Chapter B11. Determination of pesticides and pesticide degradates in filtered water by direct aqueous-injection liquid chromatography-tandem mass spectrometry. U.S. Geological Survey Techniques and Methods. Book 5. Laboratory Analysis: 73.

Schäfer, R.B., Kühn, B., Malaj, E., König, A., Gergs, R., 2016. Contribution of organic toxicants to multiple stress in river ecosystems. Freshw. Biol. 61, 2116-2128.

Schroeder, A.L., Ankley, G.T., Houck, K.A., Villeneuve, D.L., 2016. Environmental surveillance and monitoring-the next frontiers for high-throughput toxicology. Environ. Toxicol. Chem. 35, 513-525.

Schultz, M.M., Painter, M.M., Bartell, S.E., Logue, A., Furlong, E.T., Werner, S.L., et al. 2011. Selective uptake and biological consequences of environmentally relevant antidepressant pharmaceutical exposures on male fathead minnows. Aquat. Toxicol. 104, 38-47.

Scott, M.C., 2006. Winners and losers among stream fishes in relation to land use legacies and urban development in the Southeastern US. Biol. Conserv. 127, 301-309.

Shen, L., Wania, F., Lei, Y.D., Teixeira, C., Muir, D.C.G., Bidleman, T.F., 2005. Atmospheric distribution and long-range transport behavior of organochlorine pesticides in North America. Environ. Sci. Technol. 39, 409-420.

Smalling, K.L., Fellers, G.M., Kleeman, P.M., Kuivila, K.M., 2013. Accumulation of pesticides in pacific chorus frogs (Pseudacris regilla) from California's Sierra Nevada Mountains, USA. Environ. Toxicol. Chem. 32, 2026-2034.

Smalling, K.L., Reeves, R., Muths, E., Vandever, M., Battaglin, W.A., Hladik, M.L., et al., 2015. Pesticide concentrations in frog tissue and wetland habitats in a landscape dominated by agriculture. Sci. Total Environ. 502, 80-90.

Sprague, L., Nowell, L., 2008. Comparison of pesticide concentrations in streams at low flow in six metropolitan areas of the United States. Environ. Toxicol. Chem. 27, 288-298.

Stehle, S., Dabrowski, J.M., Bangert, U., Schulz, R., 2016. Erosion rills offset the efficacy of vegetated buffer strips to mitigate pesticide exposure in surface waters. Sci. Total Environ. 545-546, 171-183.

Stein, B.A., Scott, C., Benton, N., 2008. Federal lands and endangered species: the role of military and other federal lands in sustaining biodiversity. Bioscience 58, 339-347.

Stone, W.W., Gilliom, R.J., Ryberg, K.R., 2014. Pesticides in US streams and rivers: occurrence and trends during 1992-2011. Environ. Sci. Technol. 48, 1102511030.

Terando, A.J., Costanza, J., Belyea, C., Dunn, R.R., McKerrow, A., Collazo, J.A., 2014 The southern megalopolis: using the past to predict the future of urban sprawl in the Southeast US. PLoS ONE 9, e102261.

Thrupp, T.J., Runnalls, T.J., Scholze, M., Kugathas, S., Kortenkamp, A., Sumpter, J.P., 2018. The consequences of exposure to mixtures of chemicals: something from 'nothing' and 'a lot from a little' when fish are exposed to steroid hormones. Sci. Total Environ. 619-620, 1482-1492.

Turunen, J., Markkula, J., Rajakallio, M., Aroviita, J., 2019. Riparian forests mitigate harmful ecological effects of agricultural diffuse pollution in medium-sized streams. Sci. Total Environ. 649, 495-503.

U.S. Environmental Protection Agency. 2005. 40 C.F.R. § 136: Guidelines establishing test procedures for the analysis of pollutants. 40 C.F.R. $\S 136$. U.S. Environmental Protection Agency, Washington, DC, pp. 319-322.

U.S. Environmental Protection Agency. 2018 ACToR. Available from <https://actor. epa.gov/actor/home.xhtml> (accessed 22.03.18.) 
U.S. Environmental Protection Agency. 2018. iCSS ToxCast Dashboard. 2018b. (accessed 22.03.18.)

U.S. Environmental Protection Agency. 2019. ToxCast \& Tox21 Summary Files. Available from <invitrodb_v3> (accessed 5.07.19.).

U.S. Food and, Drug Administration. 2018. Approved Drug Products with Therapeutic Equivalence Evaluations (Orange Book). (accessed 29.06.18.).

Usenko, S., Landers, D.H., Appleby, P., Simonich, S., 2007. Current and historical deposition of PBDEs, pesticides, PCBs, and PAHs to Rocky Moutain National Park. Environ. Sci. Technol. 41, 7235-7241.

Van Donk, E., Peacor, S., Grosser, K., Domis, L.N.D.S., Lürling, M. 2015 Pharmaceuticals may disrupt natural chemical information flows and species interactions in aquatic systems: ideas and perspectives on a hidden global change. In: Whitacre, D., (Ed.), Reviews of Environmental Contamination and Toxicology. 235. Springer International Publishing, New York, pp. 1-15.

Van Metre, P.C., Alvarez, D.A., Mahler, B.J., Nowell, L., Sandstrom, M., Moran, P., 2017. Complex mixtures of Pesticides in Midwest US streams indicated by POCIS time-integrating samplers. Environ. Pollut. 220, 431-440.

Van Metre, P.C., Waite, I.R., Qi, S., Mahler, B., Terando, A., Wieczorek, M., et al., 2019. Projected urban growth in the southeastern USA puts small streams at risk. PLOS ONE 14, e0222714.

Vasquez, M., Lambrianides, A., Schneider, M., Kümmerer, K., Fatta-Kassinos, D., 2014. Environmental side effects of pharmaceutical cocktails: What we know and what we should know. J. Hazard. Mater. 279, 169-189.
Veith, G.D., Call, D.J., Brooke, L., 1983. Structure-toxicity relationships for the fathead minnow, Pimephales promelas: Narcotic industrial chemicals. Can. J. Fish. Aquat. Sci. 40, 743-748.

Villeneuve, D.L., Crump, D., Garcia-Reyero, N., Hecker, M., Hutchinson, T.H., LaLone C.A., et al., 2014. Adverse outcome pathway (AOP) development I: strategies and principles. Toxicol. Sci. 142, 312-320.

Warne, M.S.J. 2003. A review of the ecotoxicity of mixtures, approaches to, and recommendations for, their management. Proceedings of the Fifth National Workshop on the Assessment of Site Contamination. National Environmental Protection Council Service Corporation: Adelaide, pp. 253-276.

Warren Jr, M.L., Burr, B.M., Walsh, S.J., Bart Jr, H.L., Cashner, R.C., Etnier, D.A., et al., 2000. Diversity, distribution, and conservation status of the native freshwater fishes of the southern United States. Fisheries 25, 7-31.

Weissinger, R.H., Blackwell, B.R., Keteles, K., Battaglin, W.A., Bradley, P.M., 2018. Bioactive contaminants of emerging concern in National Park waters of the northern Colorado Plateau, USA. Sci. Total Environ. 636, 910-918.

Weston, D.P., Lydy, M.J., 2014. Toxicity of the insecticide fipronil and its degradates to benthic macroinvertebrates of urban streams. Environ. Sci. Technol. 48 $1290-1297$.

Zhang, A., Xie, X., Ye, J., Lin, C., Hu, X., 2011. Stereoselective toxicity of malathion and its metabolites, malaoxon and isomalathion. Environ. Chem. Lett. 9, 369-373. 